\title{
An Empty Donut Hole: the Great Collapse of a North American Fishery
}

\author{
Kevin M. Bailey $^{1}$
}

\begin{abstract}
Walleye pollock (Theragra chalcogramma) is North America's most abundant and lucrative natural fishery, and is the world's largest fishery for human food. The little-known demise of the "Donut Hole" stock of pollock in the Aleutian Basin of the central Bering Sea during the 1980s is the most spectacular fishery collapse in North American history, dwarfing the famous crashes of the northern cod and Pacific sardine (Sardinops sagax). This collapse has received scant recognition and became evident only in 1993 when fishing was banned by an international moratorium; nearly 20 years later it has not recovered. The history of fishing in the North Pacific Ocean after World War II offers some insights into how the Donut Hole pollock fishery developed, and the societal and economic pressures behind it that so influenced the stock's fate. Overfishing was, without a doubt, the greatest contributor to the collapse of the Aleutian Basin pollock fishery, but a lack of knowledge about population biocomplexity added to the confusion of how to best manage the harvest. Unfortunately, the big scientific questions regarding the relationship of Donut Hole fish to other stocks are still unanswered.
\end{abstract}

Key Words: Aleutian Basin; Bering Sea; commercial fisheries; conservation; North Pacific; Theragra chalcogramma; walleye pollock

\section{INTRODUCTION}

It was a blustery, gray day in February 1986, and I was on a National Oceanic and Atmospheric Administration (NOAA) research ship in the middle of the commercial fleet fishing in the "Donut Hole", an international zone in the middle of the Bering Sea between the coastal waters of the U.S. and USSR (Fig. 1). I counted 60 large factory trawlers around us belonging to four or five different nations. They lined up in a pattern of several rows to take turns dragging across a thin layer of Alaska pollock at about $400 \mathrm{~m}$ depth, fishing with cavernous nets that opened $45 \mathrm{~m}$ high for durations of several hours. That year, the Donut Hole sustained a "reported" winter catch of about 1 million tons. In hindsight, I was witnessing the extirpation of pollock in the Aleutian Basin.

Walleye pollock (Theragra chalcogramma), better known as Alaska pollock, is North America's most abundant and lucrative fishery, making up about $40 \%$ of the total U.S. fisheries landings, with a gross value of more than U.S.\$1 billion annually. It is the world's largest human food fishery. Pollock in the eastern Bering Sea is considered to be one of the world's best managed populations due to the observed stability in commercial landings (Morrison et al. 2009). However, in spite of the best efforts of harvest managers to engineer stability, fisheries ebb and flow as their target populations cycle through periods of high and low abundance.

Recent red-flag news articles in The Economist (2009) and Science (Morell 2009) expressed alarm about the health of the major stock of pollock that lives on the eastern Bering Sea shelf. Beyond the shelf, the little-known rise and fall of the pollock fishery in the Aleutian Basin (the deepwater between the continental shelves of Russia and United States) of the central Bering Sea during the 1980s ranks among the most spectacular fishery collapses to occur in the modern history of fisheries in the northern hemisphere, sharing that dubious honor with the coastal Norwegian spring spawning herring collapse of the 1970s. How did this happen and escape widespread attention?

The collapse of a fishery can be defined as a decline in catches to $10 \%$ of the maximum previous level (Mullon et al. 2005). Collapses of fisheries cause tremendous economic and social problems, as experienced in the demise of the northern cod fishery in Newfoundland/Labrador in the 1980s (Schrank 2005), the devastating effects on Monterey's cannery row after the Pacific sardine's (Sardinops sagax) decline in the 1940s (Mangelsdorf 1986), and the economic stress caused by the fall of the Peruvian anchoveta (Engraulis ringens) in the 1970s (Glantz 1979). Another example is the Bohuslän herring, whose irregular patterns of abundance near the Swedish coast over the last 500 years caused periods of feast and famine in the local economy (Smith 1994). Rapid declines in fish populations also cause major ecological problems. Disappearing fisheries can generate trophic impacts at both lower and higher levels of the food web, causing shifts in communities (Pauly et al. 1998, Frank et al. 2007) and highly visible impacts on birds and marine mammals that have grown to depend on the resource (Springer 1992).

Alaska pollock (Fig. 2) often dominates the coastal ecosystems of the North Pacific Ocean. It is a gadid species closely related to Atlantic cod (Gadus morhua). Pollock is generally thought of as a semi-demersal inhabitant of the continental shelf, ranging across the subarctic Pacific Ocean, where it has existed for about 3 million years. Given what was known about the life history of pollock, it came as a surprise in the 1970s when 
Fig. 1. The "Donut Hole" in the Aleutian Basin of the central Bering Sea.

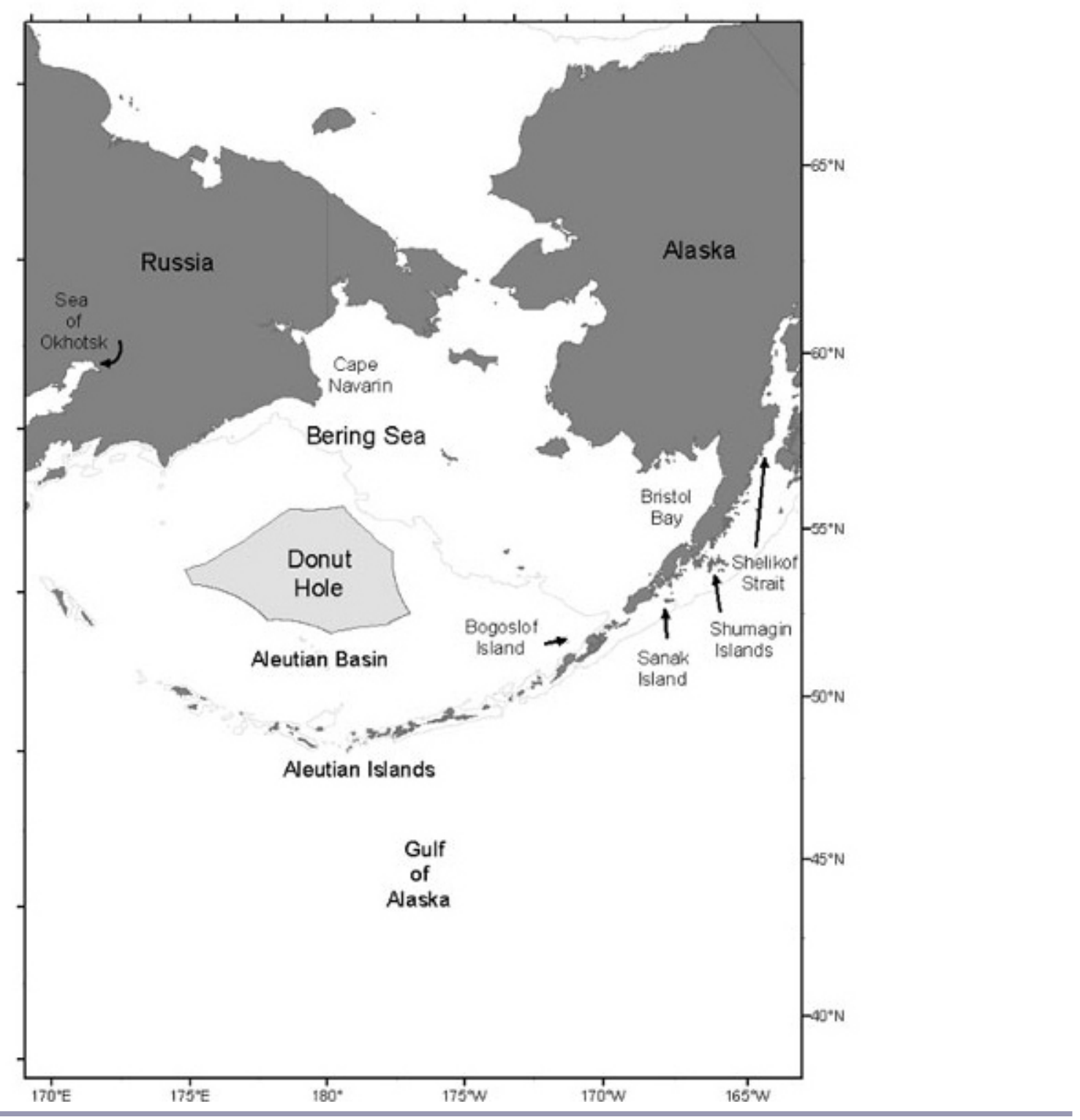

a large population was found in the very deep water over the Aleutian Basin, and a fishery for pollock quickly developed. Most of the Aleutian Basin fishing occurred in the Donut Hole, where pollock were caught in the 1980s exclusively by nonU.S. fisheries, mainly those of Japan and the (former) USSR, but also China, Poland, South Korea, and others. The Donut Hole is the equivalent of the "Smutthullet" in the Barents Sea in the international waters between Norway and Russia, and the "Peanut hole" in the Sea of Okhotsk, which are also areas of fisheries strife. Pollock in the Donut Hole were believed to be part of a greater population in the Aleutian Basin, a "straddling" population that seasonally migrates across international boundaries.
It is difficult to assess how many fish once existed in the Aleutian Basin, but fisheries scientists have used population models to estimate that a peak of nearly 13 million tons of pollock age 5 and older were in the U.S. zone of the Aleutian Basin in 1983 (Ianelli et al. 2006). This was calculated from a model that included reported catches from the Donut Hole region and from the fishery in U.S. waters that occurred in the Aleutian Basin near Bogoslof Island ${ }^{[\dagger]}$. The tonnage is equivalent to about 20 billion fish, or about three fish for every person on Earth.

The highest officially reported catch in the Aleutian Basin, including U.S. and international Donut Hole waters but excluding Russian territorial waters, was 1.7 million tons in 
Fig. 2. The walleye or Alaska pollock (Theragra chalcogramma).

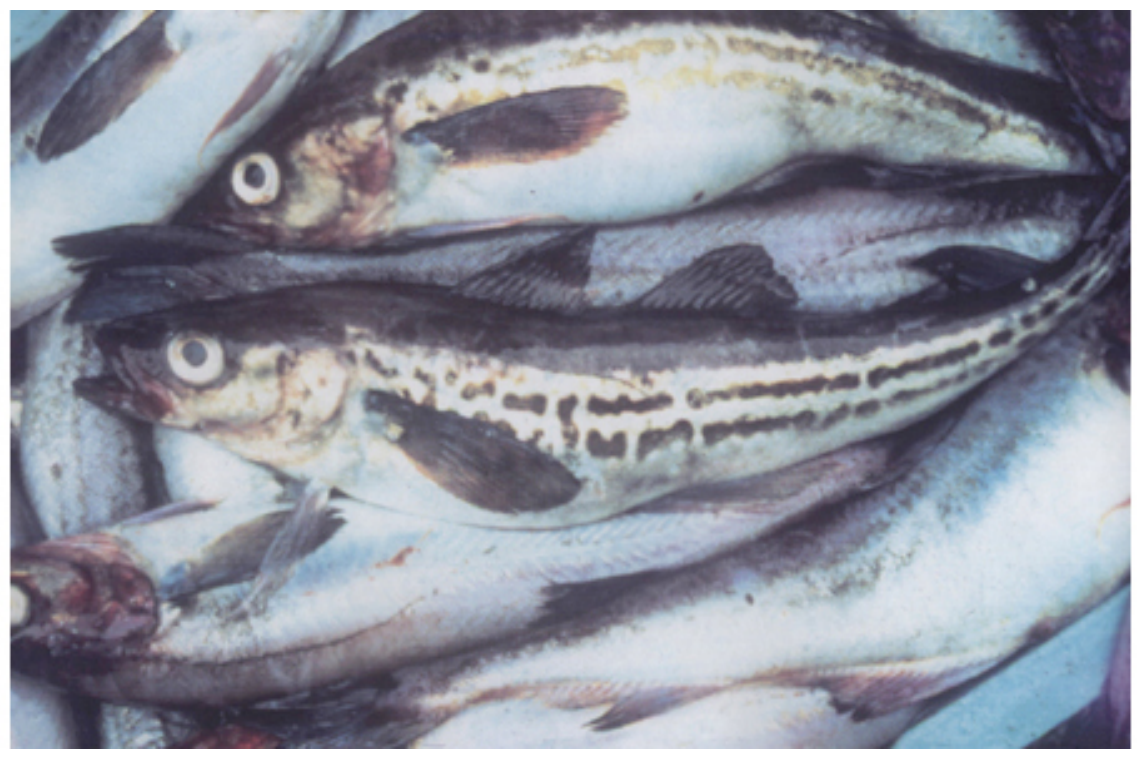

1987 (Fig. 3). By far the greatest harvest area was the Donut Hole. The catch plunged to 10 thousand tons in 1992 . The estimated biomass declined in 1988 to less than $50 \%$ of the peak abundance (while catches were increasing), and to only $6 \%$ in 1992. By any definition, a collapse had occurred.

In 2007, the biomass estimate was at its nadir of 309 thousand tons, a decline of $98 \%$ from the maximum. In fact, in that year, during a test fishery conducted under the auspices of the Bering Treaty, a pair of Korean trawlers spent 2 weeks trawling for pollock in the Aleutian Basin, and caught just two pollock. Most fish in the catches were smooth lumpsuckers (Aptocyclus ventricosus) (CBS Treaty 2007). Now, after 20 years, the population still has not recovered. Bycatch of pollock in Japanese survey longline catches in the Aleutian Basin tend to support the scenario depicted above; there was a substantial but lower background level of abundance in the 1970s, which increased in the 1980s, collapsed in the 1990s, and now hovers around zero (CBS 2010).

The demise of the Aleutian Basin pollock population has received scant attention compared to declines of other fish stocks. A search through Science Citation Index reveals only six publications with the topics/titles of pollock and Aleutian Basin. Only one publication includes both the terms pollock and Donut Hole, and none document the collapse. By contrast, there are 266 publications with the topics of cod and Canada, and 212 publications with the topics of sardine and California. This despite the fact that the Aleutian Basin pollock collapse was more than three times larger than that of the next largest fishery collapse on record. Whereas the biomass of pollock in the Aleutian Basin went from nearly 13 million tons in 1983 to 309 thousand tons in 2007, Pacific sardine had a spawning biomass of about 4 million tons in 1935, which declined over a period of nearly 20 years to about 200 thousand tons. For the northern cod, which comprises a cluster of individual stocks off the coast of eastern Canada, the spawning biomass was 1.6 million tons in 1962 and declined to less than $10 \%$ of that value by 1992 (Smedbol and Wroblewski 2002).

\section{THE SETTING}

The local and global circumstances leading to development of fishing along the west coast of North America and the Bering Sea set the stage for the complex situation underlying the collapse of pollock in the Aleutian Basin. Prior to World War II (WWII), harvest management of groundfishes was largely nonexistent, and a "common pool" approach prevailed in which no one and everyone owned the resource (NOAA 2002). In the 1940s, the United States pursued an international policy, supported by the Departments of State and Defense, of "freedom of the seas and skies", following the failure of the Pacific sardines after WWII. Sardines were critical baitfish needed to support the important and powerful tuna fishing industry, and were used in the reduction fishery, which had become important to agriculture as fertilizer and poultry feed (McEvoy 1986).

After the sardine's demise, the baitfish fishery moved south to coastal Latin America, where numerous countries tried to exclude American vessels from their territorial waters (McEvoy 1986, Finley, in press). The post WWII U.S. policy of freedom of the seas for baitfish and tuna fisheries conflicted with subsequent efforts in the Pacific Northwest to exclude Japan from harvesting salmon and king crab in Bristol Bay. The two opposing views in fisheries policy represented the internationalists, who believed that all countries should have 
Fig. 3. Comparison of reported harvests from the "Donut Hole" and Aleutian Basin to biomass levels of age 5 and older pollock in the Aleutian Basin $\ddagger$. The solid curve in the top panel is the catch in the Donut Hole; the dotted line is the total reported catch in the Aleutian Basin. The gray vertical line marks the peak of harvests, showing that it occurred well after the decline of biomass in the Aleutian Basin (data from Ianelli et al. 2006).
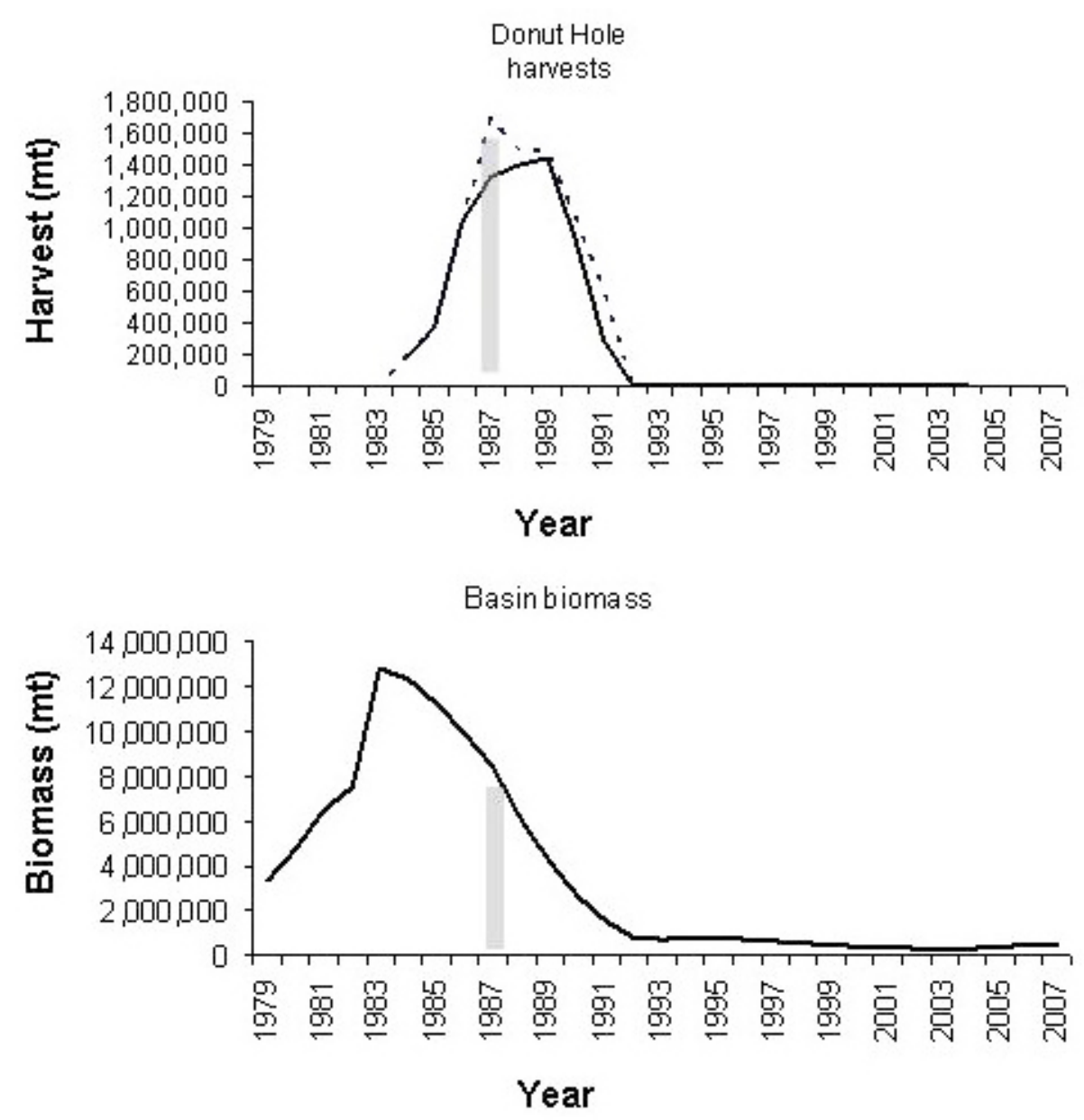

free access to the world's resources, versus the protectionists, who believed in state control of coastal resources. Wilbert Chapman, who crafted the U.S. High Seas Fisheries Policy as Undersecretary Advisor to Secretary of State George Marshall (of the Marshall Plan) in 1948, believed "The policy goals were to reinforce the Truman Proclamation of 1945, to uphold the principle of the freedom of the seas, and to establish that fish stocks could be conserved without claiming expanded territorial limits" (Watt 1979, cited in Finley 2009). The implication was that fully exploited fisheries should be managed after the point of maximum sustainable yield was attained, while underexploited fisheries should be developed.

Fishing has always been important to the food supply of Japan. Between 1895 and 1941, as Japan expanded its empire, its fisheries spread across the North and South Pacific Oceans. In the early 1900s, Japan was fishing in the Okhotsk and western Bering Seas (Miles et al. 1982). In 1930, Japan initiated a fishery for king crab in the eastern Bering Sea, and in 1933 started a trawl fishery catching groundfish for meal and fish oil (Chitwood 1969). These activities established a historical presence of Japan in the Bering Sea, the importance of which is discussed later. Fishing activity was interrupted by WWII, and afterwards the Japanese fishing fleet was devastated as most of the larger ships were destroyed.

After the war, the Supreme Command of Allied Powers (SCAP) perceived the urgency of rebuilding the Japanese fishing industry to combat massive malnutrition in occupied Japan and to help Japan become self-sufficient. An added motive was to fend off social unrest resulting from food shortages and curb the potential spread of communism (Finley, in press). The huge ship building capacity of Japan, which had developed in preparation for war, was now, with U.S. support, 
Fig. 4. U.S. observer Wayne Palsson sampling pollock aboard a foreign fishing vessel in the Bering Sea.

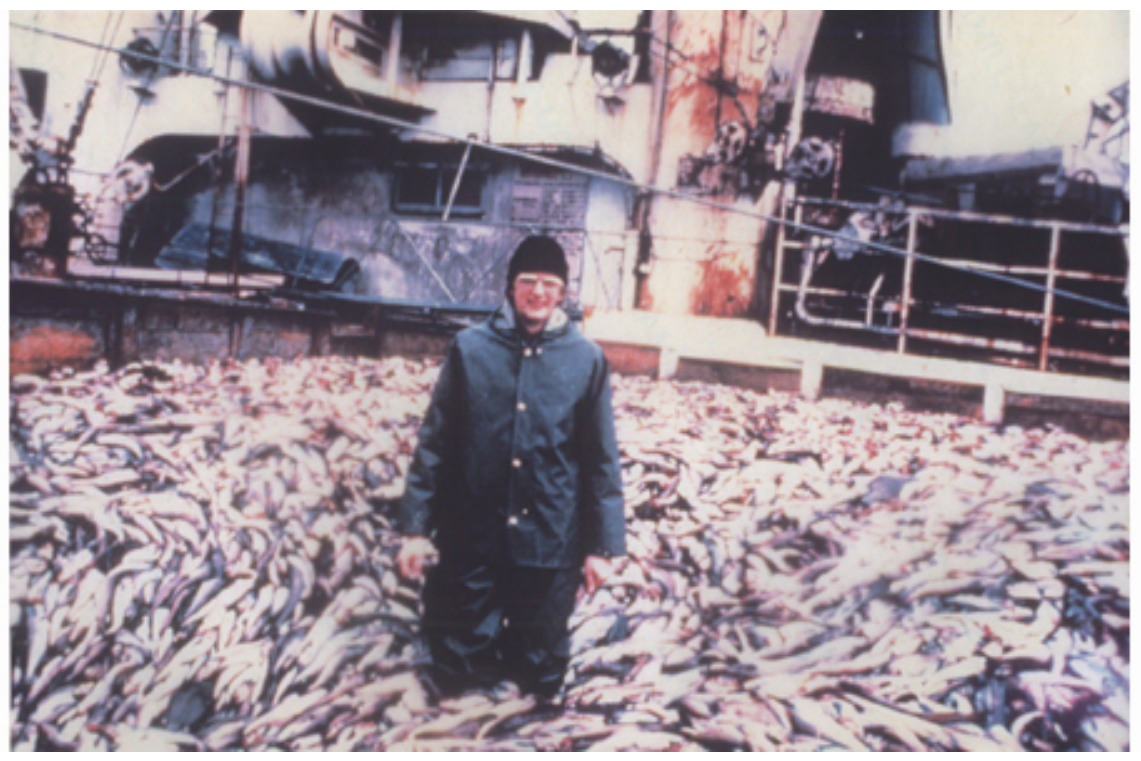

turned to rebuilding the fishing fleet (Chitwood 1969). By 1947, Japan's fleet was back to its pre-war capacity and growing at a rapid pace (Finley, in press). The right to fish in international waters, although limited in extent, had been implied by the Potsdam Declaration of 1945, which preserved Japan's right to fish in historical pre-war fishing grounds, including international waters off Alaska. In reality, the SCAP at first limited the extent of Japanese fishing to Japan's own coastal waters. But increasing pressure on local fisheries pushed the SCAP to open more distant water fisheries (Alverson 2008, Finley, in press). The Final Peace Treaty of WWII, signed in 1951, established Japan's right to re-enter the high seas fishery, and the International Convention for the High Sea Fisheries of the North Pacific signed in 1952 allowed Japan to fish in the Bering Sea. As a consequence, post-war fishing by Japan for yellowfin sole (Limanda aspera) began in the eastern Bering Sea in 1954.

As part of its own post-WWII rebuilding effort, the USSR created one of the world's largest fishing fleets (Finley, in press). In 1954, the giant factory trawler Pushkin was launched from a West German shipyard, and by 1970 there was a fleet of 400 Soviet distant water processing vessels (Hornnes 2006). In 1959, the USSR joined Japan in harvesting groundfish in the eastern Bering Sea, and that year the U.S. Coast Guard reported 100 Soviet vessels fishing the continental shelf off western Alaska (Alverson 2008). The Republic of Korea (South Korea) remodernized its fishing fleet after the Korean War and began fishing for pollock in the eastern Bering Sea in 1968 (Miles et al. 1982).

Another legacy of WWII was a tremendous leap forward in the technology of fishing. The development of Loran, radar, and echosounders assisted in safe navigation and position finding, and in locating fish. The development of strong and lightweight synthetic fibers allowed for larger nets; the old style of nets used cotton twine, which was weaker and more likely to tear, and soaked up water, which made the nets heavy. Improved propulsion made the ships faster and more powerful, and refrigeration allowed them to keep their catch from perishing and to develop distant water fishing. All of these factors paved the way for expansion and globalization of marine fisheries. In the two decades after WWII, global marine fish catches increased $300 \%$. The other important development after the war was the substantial investment by governments into fishery capacity, led by Japan, the Soviets, Norway, and the U.S.

Japan's first catches of pollock in the eastern Bering Sea were logged in 1958, and a directed fishery began in 1964. An intensive Japanese fishery for pollock in the Fox Islands (just west of Unimak Pass) developed in 1966. In the same year, the U.S. extended jurisdiction to 12 miles from the contiguous coast but allowed foreign fishing from 9 miles. For the most part, groundfish in the Bering Sea was an undeveloped fishery that was a long way from historical U.S. fishing areas and did not threaten the interests of American fishers, who were more interested in salmon, crab, and halibut (Alverson 2008).

The expanding foreign fleets were operating under the long standing concept of "freedom of the seas", and everything outside the territorial limit was available on a first-come, firstserved basis (Alverson 2008). Managing high seas fisheries was difficult because it had been established in 1955 at the International Technical Conference on the Conservation of the Living Resources of the Sea, which was held in Rome, that 
foreign fisheries could be halted only after scientific studies proved that overfishing was occurring (Finley, in press). Prior to the Fishery Conservation and Management Act (FCMA) of 1976, foreign fisheries in the eastern Bering Sea were managed by bilateral agreements beginning in 1967. By 1973-74, catch quotas were placed on eastern Bering Sea pollock, but they were self-policing and self-reporting (NOAA 2002). These policies set the background for development of the Aleutian Basin fishery.

\section{A DEVELOPING FISHERY IN THE ALEUTIAN BASIN}

Japanese scientists reported finding large concentrations of pollock in the Aleutian Basin in the 1970s and spawning pollock in the Donut Hole in 1983 (Okada 1983). By then, the scientists were a step behind, as a major commercial fishery had already started. "Official" catch records indicate that the fishery in the Aleutian Basin began in 1984, but it is clear from U.S. observer records that significant fishing had been happening at least since 1981 (Fritz 1993; Fig. 4). The fishery operated largely in winter to catch pre-spawning females for their valuable roe. The remaining carcasses and male fish were processed into surimi, a type of fish paste that is reprocessed into sausage and other products, and fish meal.

The Donut Hole fishery did not really escalate until "Americanization" of harvests within the territorial waters of the U.S. occurred, pushing foreign fisheries into the international zone of the Aleutian Basin. In 1980, about 50\% of the crab fishing industry was owned by emigrated Norwegians (Hornnes 2006). With marked declines in Bering Sea crab stocks in the early 1980s, a large portion of the Norwegian-American fleet was converted to groundfish trawlers, reinforcing a new "joint venture" fishery wherein U. S. ships caught fish and delivered them to at-sea foreign processors. U.S. fishers had first priority to the "total allowable catch" in the Fisheries Conservation Zone out to 200 miles as a result of the FCMA of 1976.

Norwegian investors financed a massive rebuilding of U.S. ships into trawlers, factory trawlers, and processors, with much of the work done in Norway and financed by Norwegian interests (Hornnes 2006). There was a huge amount of money at stake, as the typical cost of converting a ship was U.S. $\$ 38$ million (NOAA 2002). Norway's Christiana Bank alone had a loan portfolio in the Seattle-based fishery of U.S.\$435 million, and other Norwegian banks, such as Creditbank and Bergen Bank, also had large loan portfolios (Hornnes 2006).

There were also U.S. subsidies to rebuild and modernize the fleet (Weber 2001). The Japanese had a different strategy to secure access to the U.S. pollock resource: they invested in shoreside processing plants and in some processing vessels. In 1989, Japan controlled $85 \%$ of the interests in shoreside processing plants (D. Alverson, quoted in Helm 1989). Access to a limited resource led to a political battle between the inshore and offshore processors for rights to pollock harvest quotas, resulting in various allocation schemes. Flurries of protectionist bills were initiated, including the "Antireflagging Act" in 1988, various inshore/offshore processor allocation schemes, and eventually the American Fisheries Act of 1998 .

With the foreign fleet gradually being squeezed out of U.S. territorial waters by the capacity of the U.S. fleet to catch all of the total allowable catch there, the Donut Hole fishery in international waters intensified. In 1985, the reported catches from the Donut Hole reached 360 thousand tons of fish. In 1988, the North Pacific Fishery Management Council called for a moratorium on fishing in the Donut Hole, but it never happened. Reported harvests in the Donut Hole nearly quadrupled to 1.5 million tons in 1989. Two years later, the bottom fell out - the harvest dropped to 293 thousand tons, and the fishery was nearly halted in 1992 with a take of 10 thousand tons. In 1993, a moratorium was finally put in place by international agreement just prior to the 1994 signing of The Convention on the Conservation and Management of the Pollock Resources in the Central Bering Sea (hereafter, the Central Bering Treaty).

About $400 \mathrm{~km}$ to the southeast of the Donut Hole, Bogoslof Island pokes up through the surface from the abyssal plain of $3000 \mathrm{~m}$ depth. Catch statistics for the Aleutian Basin include the fishery around Bogoslof Island, but the connection between the Donut Hole and Bogoslof, although accepted by many stock assessment scientists, lacks substantial and direct evidence at present.

The fishery on pollock around Bogoslof Island was even more short-lived than that in the Donut Hole, lasting only about 5 years. A new joint venture fishery in the Bogoslof region started in 1987 with a catch of 340 thousand tons. In 1989, the harvest was 39 thousand tons, and then in 1992 catches dropped to 241 tons and the fishery was suspended prior to signing of the Central Bering Treaty in 1994. The drop in harvest levels was mirrored by a drop in acoustic survey estimates of biomass from 2.4 million tons in 1988 to 110 thousand tons in 2007. However, the decline may be underestimated because the survey area shifted: since fish became much less abundant over the deep waters of the Aleutian Basin, the survey moved closer inshore than in the earlier years. Since then, catches have varied between 10 and 100 tons per year.

Pockets of small spawning groups have been observed in the area just to the north of the Aleutian Islands (e.g., near the islands of Four Mountains and Baranof Ridge). A small fishery developed along the Aleutian chain in 1979 at a level of about 10 thousand tons and grew to a peak of 50-100 thousand tons in the early 1990s. Then, in the late 1990s, harvests dropped to about 20 thousand tons, and in 1999 the harvests were severely restricted, ostensibly to protect endangered Steller 
sea lions (Eumetopias jubatus). Over that time frame, the peak biomass of age 3 and older pollock dropped from 1.6 million to 170 thousand tons, an $89 \%$ decline. [Erratum]

It is more difficult to estimate what has happened on the Russian side of the Aleutian Basin (Vaisman 2001). Reported catches in the southwest Bering Sea peaked at 1.13 million tons in 1981 and declined steadily through the 1980-1990s to 79 thousand tons in 1995 and only 4 thousand tons in 2006 (CBS 2010), or less that $1 \%$ of the maximum catch. On the other hand, in the extreme northern part of the Bering Sea near Cape Navarin, catches have remained fairly steady.

\section{A PERSONAL NARRATIVE}

Sometimes our own personal stories as scientists collide with historical events. I did not realize it at the time, but the political history of the Bering Sea and its fisheries was an undercurrent sweeping me along my career path. My first encounter with Bering Sea fisheries was in the winter of 1974, when, as a recent graduate of the University of California at Santa Barbara, I was hired as a U.S. observer on a Japanese crab factory mothership in the frigid winter waters of the Bering Sea. Over the next four months, there were many times when I wondered exactly how I had arrived there.

My job as an observer on the Japanese mothership was to monitor species composition and take biological measurements as the smaller catcher vessels made their deliveries. Two observers were deployed, and after we got settled on-board, my partner and I took it upon ourselves to go beyond our official instructions of just observing. We tried to estimate Japanese harvest levels (which was not our assignment) by counting all of the crabs in several bags delivered to the mothership - a number we multiplied by the average weight of individual crabs and the number of bags delivered to obtain tonnage landed. We replicated the process several times, and then compared our estimated catch to that given by the factory manager.

Our estimates were about double the reported catches! All signs pointed to the scales being inaccurately calibrated, whether intentionally or not. We naively reported the discrepancies back to the ship's fishing manager, and very suddenly our relationship with the friendly crew of about 300 sailors soured and a tense situation ensued. A confined and isolated gathering of nice individuals became a hostile crowd. Fearing for his life, my partner left a note with me intended for his parents in case he disappeared. After another week of duress, he arranged to leave for home, while I was asked by headquarters to wait for replacements and train them, a process that lasted for another two months.

After this experience, I vowed that my career at sea was over. But by the next winter, I ran out of money and once again I found myself in the Bering Sea, this time aboard a Japanese pollock factory trawler during one of the coldest winters on record. Because of poor fishing related to the heavy ice conditions on the fishing grounds, the ship returned to Japan after only a couple of weeks.

Skipping ahead through the graduate school years, by 1986 I had become a research biologist engaged as the chief scientist on a NOAA research ship in the Donut Hole in response to a growing concern about the foreign fishery there. We had an ambitious plan: our survey was to determine where the fish were spawning, to collect eggs and larvae for natural history studies, and to determine where the fish came from using genetics and the chemical composition of their otolith ear stones (Fig. 5) to track their birth origin based on elemental fingerprints.

Locating a densely packed spawning aggregation in the Aleutian Basin, an area spanning more than 1 million $\mathrm{km}^{2}$, is like finding the proverbial needle in a haystack. Fish are found by searching along a transect while traveling at about $15 \mathrm{~km} /$ $h$ and looking underneath the vessel path with an acoustic beam that is several meters wide. Instead, we decided to rely on U. S. observers on foreign fishing vessels to report by radio where they were finding spawning fish. With more than 100 vessels plying the waters for several months, this considerably enhanced our probability of finding a spawning aggregation. The strategy paid off: we did in fact find spawning fish in locations where observers had reported them. The results of our studies indicated interesting, but inconclusive, differences in Donut Hole fish compared to those collected from adjacent regions. In hindsight, the technology available and the sample sizes obtained based on meager funding levels, did not have the resolving power to distinguish the small differences we might have expected.

After 1986, research on the Donut Hole pollock waned partly because the core of scientists interested in the scientific problems had dissipated: I was transferred to another program in the Gulf of Alaska and several others left for academic or administrative positions. Eventually, more alarm about the status of the fishery generated efforts to mount a new research program, but a large ship is needed to work in the Bering Sea at considerable expense. By the time funding and ship time were finally secured in 1993, the Aleutian Basin population had already crashed. Scientists in this program spent two research seasons looking for pollock eggs and larvae in the area; when they were unable to find sufficient numbers to justify continuing, they adjusted their objectives and transferred their operations to the eastern Bering Sea shelf, where fish were still plentiful. Since then, research conducted by U.S. scientists in the Aleutian Basin has been limited mostly to acoustic assessment surveys near the Aleutian Islands.

\section{CAUSES OF THE DECLINE}

What went wrong in the Donut Hole? An alignment of critical events concentrated a large fishery into a small area, and catches in the international waters of the Donut Hole were 
Fig. 5. Head of a larval Alaska pollock. The otoliths are tiny specs in the saccule behind the eye. Inset shows a picture of a dissected otolith with daily growth increments.

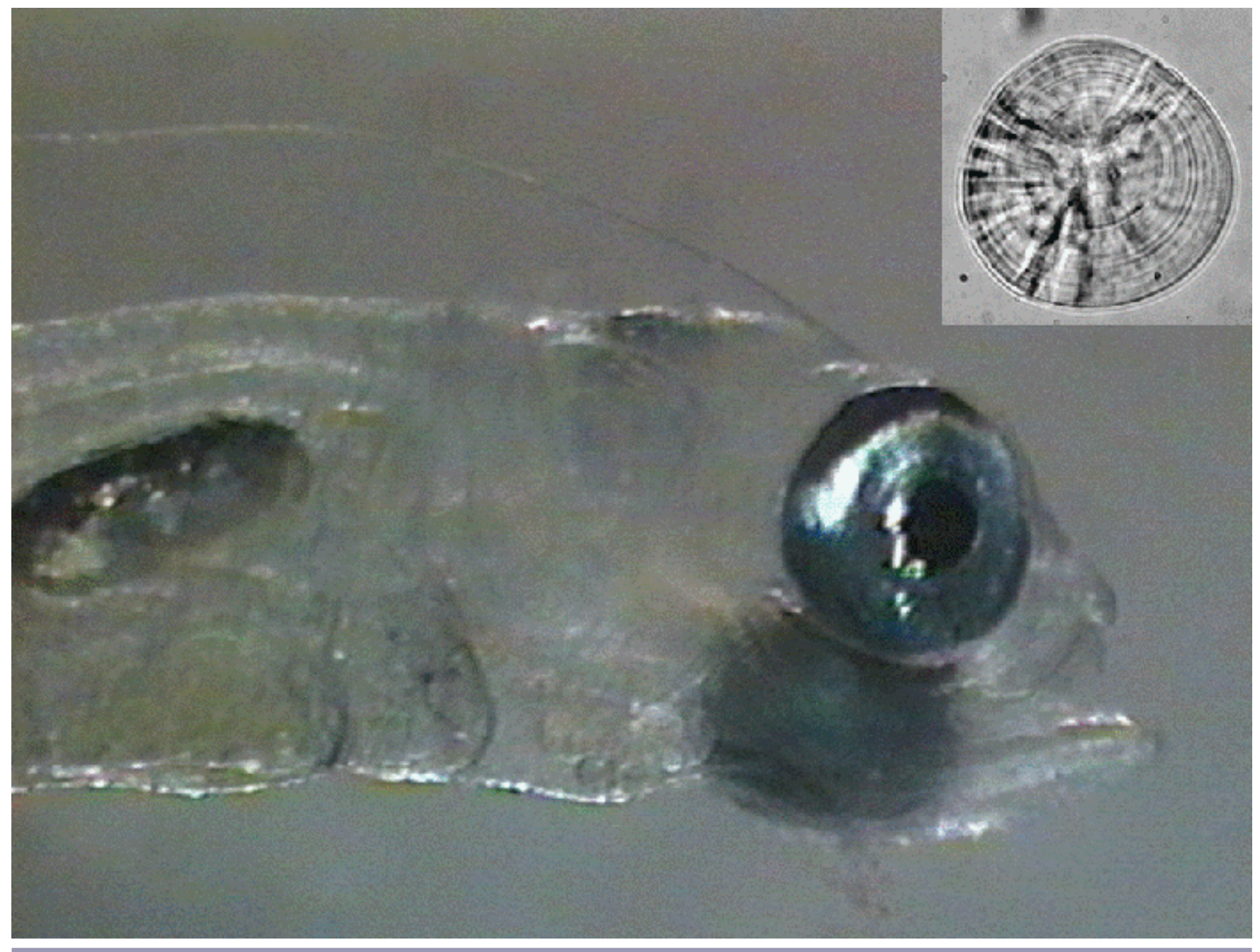

unregulated and probably misrepresented. By the time the fishery was halted by the moratorium in 1993, it was too late. Japanese scientists estimated that there were 148 vessels fishing for pollock in the Donut Hole in 1986-87, and the efficiency of gear and the methods for catching pollock were constantly improving (Sasaki and Yoshimura 1987). Anecdotal observations in the 1980s indicated annual harvests were as high as 3 million tons (Seattle Times 1992) and even 5 million tons (Miller 1987). At that time, the biomass of fish in the Aleutian Basin and Donut Hole was uncertain (Miller 1987).

In retrospect, the harvest levels were still increasing in the late 1980 s, even as the stock was crashing; the harvest ran ahead of knowledge of the status of the resource, which is common in start-up fisheries (Greenberg 2010). It is clear from historical documents (Miles 1989) that experts in the field, although recognizing the potential for a dangerous situation, did not realize the declining state of the population in 1989 when the harvest peaked. Illegal fishing outside of the international zone in U.S. waters and underreporting of catches on a massive scale were suspected; several Notes Verbales were issued by the U.S. State Department charging evidence of organized industry conspiracies to cheat (Miles 1989). In response, the national government of Japan distributed strict punishment to proven offenders, but effectively patrolling the expanse of the distant sea and catching them was difficult. Socalled IUU (illegal, unreported, and unregulated) fishing probably occurred with Soviet pollock fisheries in the western Bering Sea, and this continued to be a serious problem in the Russian Exclusive Economic Zone of the Bering Sea (Vaisman 2001).

Intensive fishing pressure was set up by a collision of events, resulting in overfishing to the point of "commercial extinction" (Baird 2004). Declining crab harvests in the 1980s, 
a rise in the price of frozen fish, and a favorable currency exchange stimulated the conversion of many crabbers and other ships to trawlers. The FCMA set up conditions for the Americanization of the groundfish fishery in U.S. waters, which had the unintended consequence of forcing the large foreign fishery into the Donut Hole, where it was unregulated (Miles 1989). There, the pollock fell to recently developed acoustic technology (another outcome of WWII) that was used to find and catch fish proficiently. The attitude of high seas foreign fisheries at the time contributed to the collapse: the resources of the open seas were considered boundlesseverything outside of sovereign waters was available on a firstcome, first-served basis, and under "pulse" fishing, harvesters pounded one area and then moved on to more productive ones (Alverson 2008). There was still a prevalent belief that there existed a surplus of unutilized fish in the ocean. Perceptions have changed slowly since passage of the U.S. Endangered Species Act and the Marine Mammal Protection Act in the early 1970s, which pointed out the forage needs of other ecosystem components, whereas prior to that, the industry's search for profit had been the primary concern (McEvoy 1986). Such considerations took hold in the Bering Sea fishery with the closure of the Aleutian Island's pollock fishery and some areas of the shelf in 1999 to preserve Steller sea lion habitat.

\section{UNANSWERED QUESTIONS}

Understanding the nature of what we are trying to manage remains one of the most vexing problems of fisheries management. The question regarding the relationship of Donut Hole fish to other stocks remains unanswered after some 20 years. Overfishing in the Donut Hole was complicated by the uncertainty of the connection of the Donut Hole aggregation to other spawning groups. This is an uncertainty that will persist until the population rebuilds-if it does. Interestingly, the Soviets believed that the Aleutian Basin fish were closely connected to stocks over their continental shelf, and the Americans made a similar claim for themselves, that is, straddling stocks, while the countries without a coastline on the Bering Sea claimed that the Aleutian pollock were an independent stock (Miles 1989). As usual, each nation viewed the data in light of its own self-interest (Alverson 2008).

The Aleutian Basin has been little studied before and after the collapse of pollock there. An obvious cause for a rise and decline would be an environmental effect. However, there is no obvious relationship of pollock dynamics in the area with temperature changes (Akira et al. 2001: Fig. 7). There also does not appear to be a change in the abundance of zooplankton prey of pollock that could explain the collapse. Although zooplankton in the Aleutian Basin declined from 1993 to 1995 (Hunt et al. 2005: Fig. 49), by then the collapse of the pollock stock had already happened.

The consensus view reported in National Marine Fisheries Service stock assessment documents is that pollock in the
Aleutian Basin were surplus fish overflowing from the shelf population as a density-dependent response. Wespestad (1993) states "Research shows that pollock harvested in the central Bering Sea move from the adjacent shelf populations. Recruits to the basin are coming from another area, most likely the surrounding shelves." Likewise, "Strong year classes of pollock in Bogoslof may be functionally related to abundance on the shelf", and "Collectively, pollock found in the Donut Hole and in the Bogoslof region are considered a single stock, the Aleutian Basin stock" (Ianelli et al. 2006). The main support behind these assertions is that some of the same strong year classes that appeared in the Aleutian Basin were also strong over the shelf. This observation led to the hypothesis of density-dependent overflow into the basin from the adjacent shelf, known as the "serendipity hypothesis", which postulates that fish were from a couple of very strong year classes over the surrounding continental shelf waters (J. Ianelli, personal communication). I am less certain about the biological relationship of shelf and Basin pollock.

In the early 1900s, the iconic Norwegian scientist Johan Hjort (1926) showed that fish stocks are not fluctuating because of large-scale migrations but rather due to interannual variability in year-class strength. Although environmental conditions may cause temporary distribution shifts, large-scale and semipermanent displacements of fish populations similar to that described for pollock in the Aleutian Basin are somewhat rare. A well-known shift in Iceland-Greenland juvenile cod is caused by anomalous currents that transport them towards Greenland and away from their usual nurseries; however, fish return to natal spawning grounds as adults (Storr-Paulsen et al. 2004). Density-driven migration excursions are also observed in capelin, although the maintenance of these patterns is not clear (Fauchald et al. 2006). One of the best known examples of large-scale migration is that of the "Bohuslän herring", which appear in great quantities off the west coast of Sweden at a frequency of about once a century and maintain high levels of abundance for several decades. One hypothesis put forth to explain the Bohuslän herring phenomenon is that a very strong year class of herring in the North Sea, combined with an environmental window, allows them to enter deep into the Skagerak, which starts the overwintering pattern. They learn this migratory path, then other new year classes learn the behavior by following the older fish (Corten 1999). However, Cushing (1975) also suggests that the region could be seeing the effect of waxing and waning local populations. Since the Bohuslän herring has not appeared for the last 100 years, direct testing of the alternative hypotheses has not been possible.

The situation in the Aleutian Basin discussed above is a little different from the other fisheries. First, fish were not just overwintering in the Basin, they were spawning there (Okada 1983, Hinckley 1986, Mulligan et al. 1989, Traynor et al. 1990). Second, juveniles were rarely caught in the Basin, 
leading to the assertion that eggs and larvae were transported onto the eastern shelf, where they would spend their juvenile life, and then migrate to the Basin, where they would remain throughout their adult life. Data directly supporting either the notion that Aleutian Basin fish were a self-sustaining population or that their occurrence was due to an overflow of fish from the shelf to the Basin are lacking, although very much needed. It seems noteworthy to me that the maximum population in the Aleutian Basin exceeded that ever observed over the eastern Bering Sea shelf, and it seems unusual that a "surplus" would be larger than the source. And such massive displacement over the distance of nearly $500 \mathrm{~km}$ that separates the major spawning areas would be unprecedented. It may be just as plausible that the Basin was the source population that seeded the shelf with juveniles.

The "local population concept" maintains that pollock, like other fish, may be organized into multiple spawning groups, or stocks, that over the millennia have become well-adapted to their chosen habitat. This is the perspective of "biocomplexity", which suggests that fish populations may have a "portfolio" of subpopulations that dampen the variability observed in individual stocks (Schindler et al. 2010). Under these circumstances, as an individual spawning population is decimated or its habitat becomes unsuitable for spawning, the population may be lost for a considerable time until recolonization establishes a new population. Nature's experiments with colonization can result in a successful selfsustaining population, or in a population sinkhole that attracts new recruits to a poor survival habitat, known as a spawning trap.

If the Aleutian Basin pollock was a self-sustaining population and if experience with closely related species holds, successful recolonization and rebuilding of the pollock population in the Basin may take considerable time. In the case of the northern cod, many local spawning groups were decimated, and they have not rebounded some 20 years later. In the Gulf of Maine, the coastal cod collapsed in the 1940s, and in 40 of 90 historically documented coastal spawning locations, they have not reappeared for more than a half century (Ames 2004); in other words, the population has yet to recover (Brooks and Sumaila 2006). Only recently is there sign that some stocks are starting to reappear (Ted Ames, cited in Greenberg 2010: 152). Meanwhile, the Bohuslän herring has been absent from coastal Sweden for more than a century (Corten 1999).

Some other pollock stocks share similar histories with that of the Aleutian Basin. A small local spawning population in south Puget Sound disappeared around 1989 and has yet to recover. In the Gulf of Alaska, a small fishery started in 1964, and it gradually built up. Catches peaked in 1984 at 304 thousand tons and then dropped dramatically to 70 thousand tons in 1987. Within the Gulf of Alaska there are smaller aggregations of fish that spawn in discrete areas in winter-spring, including in Resurrection Bay, Prince William Sound, Shelikof Strait, Shumagin Islands, and Sanak Islands regions. The wintertime acoustic assessment of fish in the Shelikof Strait population of the Gulf was 2.8 million tons in 1981, which declined steadily to one-tenth of that value in 2008. As the main aggregation in Shelikof Strait declined, the fishery effort shifted to other areas. In the Shumagin Islands region, biomass was assessed at 300 thousand tons in 1995, and dropped to 30 thousand tons in 2008. Likewise, the Sanak population declined from 70 thousand tons in 2003 to 20 thousand tons in 2008. Over the continental shelf of the eastern Bering Sea, pollock have fared somewhat better, but the peak biomass of 12.8 million tons (age 3 and above) in 1995 dropped to about one-third of that value to 4.2 million tons in 2007, although it seems to be increasing again in 2011. Overall, the total catches in the eastern Bering Sea (including catches in the Aleutian Basin) dropped from an apex of 2.7 million tons in 1987 to 815 thousand tons in 2009.

\section{EPILOGUE}

The social and ecological effects of the pollock collapse in the Aleutian Basin are hard to compare to the examples of northern cod and California sardine. First, being a distant water fishery, it did not have as great an impact on local fishing communities. Second, less is known about the actual circumstances behind the collapse. And third, the effects on the ecosystem are largely unknown. The Aleutian Basin pollock received little attention in spite of the dramatic population decline, perhaps because the fishery was far out in the high seas where it had a relatively small impact on coastal communities. From socioeconomic and cultural points of view, pollock were not the centerpiece of trade, and did not provide subsistence to Native American fishers or employ recently settled immigrant populations. Furthermore, any bird and mammal populations in the Donut Hole that fed on pollock and were impacted by the collapse of the fishery were largely invisible to human observation because of their remoteness.

Managing complex and valuable fisheries such as pollock is difficult and full of uncertainty and questions. How can we best assess the abundance of fish living across such a vast and inhospitable area as the Bering Sea? How do we define and set sustainable harvest levels? More complications arise in terms of bycatch influences on other fisheries and ecosystems. There are conflicts in rebuilding strategies: Japanese and Korean scientists have argued that there should be a harvest quota at any level of stock biomass of the remaining fish in the Aleutian Basin, whereas the current regime under the CBS Treaty waits for the stock to recover to a certain level before a harvest is allowed (report of the $1^{\text {st }}$ treaty meeting, see CBS Treaty 2007). There are social questions about the meaning of a sustainable yield (self-sustaining, industry-sustaining, or ecosystem-sustaining), intertwined with the cultural issues of human's place in ecosystems with rights to harvest some portion, the pressure of increasing demand for seafood, and 
the need to leave some fish in the sea for other animals. Who owns fish that live part of their life in international waters? Is the resource best managed as a common pool resource or by individual privilege of catch quotas? These are all large and complex issues without easy answers. How humans see themselves and their roles in the ecosystem is going to vary considerably across the political, religious, and cultural landscape. Compared to these complex societal issues, the science questions would seem rather simple, yet have evaded the simple answers we expect.

\section{RESPONSES TO THIS ARTICLE}

Responses to this article are invited. If accepted for publication, your response will be hyperlinked to the article. To submit a response, follow this link. To read responses already accepted, follow this link.

\section{ACKNOWLEDGMENTS}

I thank Carmel Finley, Chuck Fowler, Mike Macy, Jim Ianelli, Stan Kotwicki, Valerio Bartolino, Ingrid Spies, Knut Vollset, Jeff Napp, David Fluharty, Gary Duker, Chris Baier, and Janet Duffy-Anderson for comments and advice on the manuscript. Exchanges with Rune Hornnes and Vera Schwach were very helpful. C. Finley kindly allowed me to view an in press, but as yet unpublished, manuscript of her book, which I drew from heavily.

\section{LITERATURE CITED}

Akira, N., T. Yanagimoto, K. Mito, and S. Katakura. 2001. Interannual variability in growth of walleye pollock, Theragra chalcogramma, in the central Bering Sea. Fisheries Oceanography 10:367-375.

Alverson, D. L. 2008. Race to the sea: the autobiography of a marine biologist. iUniverse, Inc., New York, New York, USA.

Ames, E. P. 2004. Atlantic cod stock structure in the Gulf of Maine. Fisheries 29(1):10-28.

Baird, R. 2004. Illegal, unreported and unregulated fishing: an analysis of the legal, economic and historical factors relevant to its development and persistence. MelbJlIntLaw 13; (2004) 5(2) Melbourne Journal of International Law 299. [online] URL: http://www.austlii.edu.au/au/journals/MelbJIL /2004/13.html.

Brooks, P. M., and U. R. Sumaila. 2006. Without drastic measures, Gulf of Maine cod fishery will be lost forever. Portland Press Herald/Maine Sunday Telegram, Sunday, April 2, 2006. [online] URL: http://www.seaaroundus.org/ne wspapers/2006/MaineSundayTelegram April2006.pdf.

CBS Treaty. 2007. Report of the Twelfth Annual Conference of the Parties to the Convention on the Conservation and Management of Pollock Resources in the Central Bering Sea. September 4-5, 2007, Beijing, China. [online] URL: http://w
ww.afsc.noaa.gov/REFM/CBS/Docs/12th\%20Annual\% 20Conference/12th\%20Annual $\% 20$ Donut $\% 20$ Hole $\% 20$ Final $\%$ 20Report.pdf.

CBS Treaty. 2010. 15th Annual Conference of the Parties to the Convention on the Conservation and Management of Pollock Resources in the Central Bering Sea. Virtual conference hosted by the United States. [online] URL: http:// www.afsc.noaa.gov/REFM/CBS/15th annual conference.htm

Chitwood, P. E. 1969. Japanese, Soviet and South Korean fisheries off Alaska: development and history through 1966. U.S. Department of the Interior, Bureau of Commercial Fisheries, Circular 310.

Corten, A. 1999. A proposed mechanism for the Bohuslän herring periods. ICES Journal of Marine Science 56:207-220.

Cushing, D. H. 1975. Marine ecology and fisheries. Cambridge University Press, Cambridge, New York, USA.

Fauchald, P., M. Mauritzen, and H. Gjosaeter. 2006. Densitydependent migratory waves in the marine pelagic ecosystem. Ecology 87:2915-2924.

Finley, M. C. 2009. The social construction of fishing, 1949. Ecology and Society 14(1):6. [online] URL: http://www.ecolo gyandsociety.org/vol14/iss1/art6/.

Finley, M. C. In press. All the fish in the sea: fish, fisheries science, and foreign policy, 1930-1960. University of Chicago Press, Chicago, Illinois, USA.

Frank, K. T., B. Petri, and N. L. Shackell. 2007. The ups and downs of trophic control in continental shelf ecosystems. Trends in Ecology and Evolution 22:236-242. DOI:10.1016/ j.tree.2007.03.002.

Fritz, L. 1993. Trawl locations of walleye pollock and Atka mackerelfisheries in the Bering Sea, Aleutian Islands and Gulf of Alaska from 1977-92. Alaska Fisheries Science Center Processed Report 93-08.

Glantz, M. H. 1979. Science, politics and economics of the Peruvian anchoveta fishery. Marine Policy 3:201-210.

Greenberg, P. 2010. Four fish: the future of the last wild food. Penguin Press, New York, New York, USA.

Helm, L. 1989. Catch as catch can...Seattle's factory trawlers run into an Alaskan storm. Seattle Post Intelligencer, October 23, 1989, B3.

Hinckley, S. 1986. Spawning dynamics and fecundity of walleye pollock (Theragra chalcogramma) in the eastern Bering Sea. Thesis. University of Washington, Seattle, Washington, USA.

Hjort, J. 1926. Fluctuations in the year classes of important food fishes. Journal du Conseil 1:5-38. 
Hornnes, R. 2006. Norwegian investments in the U.S. factory trawler fleet, 1980-2000. Thesis. University of Bergen, Bergen, Norway.

Hunt, G. L., and K. F. Drinkwater, editors. 2005. Background on the climatology, physical oceanography and ecosystems of the sub-Arctic seas. Appendix to the ESSAS Science Plan. GLOBEC Report No. 20.

Ianelli, J. N., T. Hokalehto, and N. Williamson. 2006. An agestructured assessment of pollock (Theragra chalcogramma) from the Bogoslof Island region. Pages 201-236 in Stock assessment and fishery evaluation report: Bogoslof pollock. North Pacific Fishery Management Council, Anchorage, Alaska, USA. [online] URL: http://www.afsc.noaa.gov/refm/ docs/2006/BOGpollock.pdf.

Mangelsdorf, T. 1986. History of Steinbeck's Cannery Row. Western Tanager Press, Santa Cruz, California, USA.

McEvoy, A. F. 1986. The fisherman's problem. Ecology and law in the California fisheries, 1850-1980. Cambridge University Press, New York, USA.

Miles, E. L. 1989. The U.S./Japan fisheries relationship in the northeast Pacific: from conflict to cooperation? Fisheries Management Foundation and Fisheries Research Institute, FMF-FRI-002, University of Washington, Seattle, Washington, USA.

Miles, E., S. Gibbs, D. Fluharty, C. Dawson, and D. Teeter. 1982. The management regime of marine regions: the North Pacific. University of California Press, Berkeley, California, USA.

Miller, C. 1987. How many pollock in donut hole? Alaska Fisherman's Journal October 1987:54-56.

Morell, V. 2009. Can science keep Alaska's Bering Sea pollock fishery healthy? Science 326(5958):1340- 1341.

Morrison P. C. J., M. Torres, and R. G. Felthoven. 2009. Fishing revenue, productivity and product choice in the Alaskan pollock fishery. Environmental and Resource Economics 44:457-474. DOI 10.1007/s10640-009-9295-3.

Mulligan, T. J., K. M. Bailey, and S. Hinckley. 1989. The occurrence of larval and juvenile walleye pollock, Theragra chalcogramma, in the eastern Bering Sea with implications for stock structure. Pages 471-490 in Proceedings of the International Symposium on the Biology and Management of Walleye Pollock. Alaska SeaGrant Rep. No. 89-1, Fairbanks, Alaska, USA.

Mullon, C., P. Fré, and P. Cury. 2005. The dynamics of collapse in world fisheries. Fish and Fisheries 6:111-120.

National Oceanic and Atmospheric Administration (NOAA). 2002. Final environmental impact statement for American Fisheries Act, Amendments 61/61/13/8. United States
Department of Commerce, National Oceanic and Atmospheric Administration, National Marine Fisheries Service Alaska Region, February 2002. [online] URL: http://www.fakr.noaa. gov/sustainablefisheries/afa/eis2002.pdf.

Okada, K. 1979. Biomass estimates for the pelagic pollock on the Aleutian Basin based on the echo sounder and mid-water trawl in 1978. Document submitted to the International North Pacific Fisheries Commission, August 1979. Far Seas Fisheries Research Laboratory, Shimizu, Japan.

Okada, K. 1983. Biological characteristics and abundance of the pelagic pollock in the Aleutian Basin. International North Pacific Groundfish Symposium, 1983, Paper No. P-9. Far Seas Fisheries Research Laboratory, Japan.

Pauly, D., V. Christensen, J. Dalsgaard, R. Froese, and F. Torres. 1998. Fishing down marine food webs. Science 279L:860-863. DOI:10.1126/science.279.5352.860.

Sasaki, T., and T. Yoshimura. 1987. Past progress and present condition of the Japanese pollock fishery in the Aleutian Basin. Annual Meeting of the International North Pacific Fisheries Commission, October 1987, Vancouver, British Columbia, Canada. Fisheries Agency of Japan, Tokyo, Japan.

Schindler, D. E., R. Hilborn, B. Chasco, C. P. Boatright, T. P. Quinn, L. A. Rogers, and M. S. Webster. 2010. Population diversity and the portfolio effect in an exploited species. Nature 465:609-612.

Schrank, W. E. 2005. The Newfoundland fishery: ten years after the moratorium. Marine Policy 29:407-420.

Seattle Times. 1992. The doughnut-hole pact—overfished Bering Sea will get a welcome break. August 27, 1992. [online] URL: http://community.seattletimes.nwsource.com/archive/? date $=19920827 \&$ slug $=1509661$.

Smedbol, K. R., and J. S. Wroblewski. 2002. Metapopulation theory and northern cod population structure: interdependency of subpopulations in recovery of a groundfish population. Fisheries Research 55:161-174.

Smith, T. D. 1994. Scaling fisheries. Cambridge University Press, Cambridge, UK.

Springer, A. M. 1992. A review: walleye pollock in the North Pacific. How much difference do they really make? Fisheries Oceanography 5:205-223.

Storr-Paulsen, M., K. Wieland, H. Hovgard, and H. Rä. 2004. Stock structure of Atlantic cod (Gadus morhua) in West Greenland waters: implications of transport and migration. ICES Journal of Marine Science 61:972-982.

The Economist. 2009. A tale of two fisheries. Sept. 10, 2009. [online] URL: http://www.economist.com/node/14401157?st ory $\mathrm{id}=\mathrm{E} 1 \mathrm{TQQDTTVS} \& \& \mathrm{CFID}=170225468 \& \mathrm{CFTOKEN}$ $=52527530$. 
Traynor, J. J., W. A. Karp, T. M. Sample, M. Furusawa, T. Sasaki, K. Teshima, N. J. Williamson, and T. Yoshimura. 1990. Methodology and biological results from surveys of walleye pollock (Theragra chalcogramma) in the eastern Bering Sea and Aleutian Basin in 1988. Pages 69-99 in LohLee Low, editor. Proceedings of the Symposium on Application of Stock Assessment Techniques to Gadids. International North Pacific Fisheries Commission Bulletin 50. Seattle, Washington, USA.

Vaisman, A. 2001. Trawling in the mist. Industrial fisheries in the Russian part of the Bering Sea. Cambridge: TRAFFIC Network Report. [online] URL:

http://www.traffic.org/fisheries-reports/traffic pub fisheries5. pdf.

Watt, D. C. 1979. First steps in the enclosure of the oceans: the origins of Truman's proclamation on the resources of the continental shelf, 28 September 1945. Marine Policy:211224.

Weber, M. 2001. From abundance to scarcity. Island Press, Washington, D.C., USA.

Wespestad, V. G. 1993. The status of Bering Sea pollock and the effect of the "Donut Hole" fishery. Fisheries 18(3):18-24.

${ }^{[*]}$ The estimate may also contain some unknown portion of the shelf stock that may have "wandered" into the Basin and been caught there (J. Ianelli, personal communication). Another index gives a much lower estimate of maximum biomass of pollock in the Aleutian Basin-about 4 million tons (CBS 2010). This index takes the abundance of fish determined by an acoustic survey conducted near Bogoslof Island during a 2-week period in February-March and assumes that they represent $60 \%$ of the total Aleutian Basin population. My view is that this method is less reliable because the area surveyed in February-March is small relative to the overall distribution of pollock at that time (Okada 1983, Hinckley 1986, Mulligan et al. 1989), the catches in the Bogoslof Island region were very small relative to those in the rest of the Basin, and the $60 \%$ assumption has little basis for assignment. Furthermore, from one of the few pre-exploitation surveys of the Basin, Okada (1979; cited in Okada 1983) reported a biomass of pollock in the Aleutian Basin of up to 5.4 million tons in 1978, prior to the reported increase in abundance in the 1980s.

${ }^{[*]}$ It is uncertain whether the population abundance prior to the availability of fisheries statistics increased as shown in Fig. 3 or whether it was also at a high level at some point in the past because as the fishing effort increases and expands there has been a tendency to show increased biomass as a function of discovery and increasing efficiency.

[Erratum] The original sentence "Over that time frame, the peak biomass in the Aleutian Islands dropped from 1.6 million to 1.7 thousand tons, a $99 \%$ decline." has been corrected to
"Over that time frame, the peak biomass of age 3 and older pollock dropped from 1.6 million to 170 thousand tons, an 89\% decline." The correction was made on 10 August 2012. 